\title{
Description of two new species of the Genus Megophrys, Pelobatidae (Amphibia: Anura ) from China
}

\author{
Liang Fei, Chang-yuan Ye \\ (Chengdu Institute of Biology, Academia Sinica 610015) \\ Yong-zhao Huang \\ (Chongqing Museum of Natural History, Sichuan 630700)
}

Abstract: In 1975 and 1987, two species of Megophrys were collected separately in Yizhang, Hunan and Jingdong, Yunnan. Afterwards, we compared them to existing species of Megophrys, especially to the similar species M. lateralis (Anderson) using external morophology and characters of the skull. We found they were greatly different, so we regard them as two new species, $M$. mangshanensis and $M$. glandulosa. This article gives a description of the morphology and ecology of these two new species.

Key words: Amphibia, Pelobatidae, Megophrys mangshanensis new species, $M$. glandulosa new species, systematics.

During our expeditions to Yizhang, Hunan in 1975, and Jingdong, Yunnan in 1987, we found two types of species of Megophrys, Pelobatidae. After a comparison of these species to existing species of the genus, we found their body sizes, shapes, and morphological characters to be very close to $M$. lateralis. After further studies of these three similar species using their external morphology and the characters of skull, we found them distinctly different (please see Table 1, figure 1-4 and Liu, 1961). Therefore, we believe the two specimens collected from Jingdong, Yunnan and Mangshan, Hunan are new species and we name them as M. glandulosa and M. mangshanensis.

Type specimens are all kept in Chengdu Institute of Biology, Academia Sinica.

Now the description of the morphology and ecology are recorded as follows:

\section{Megophrys glandulosa Fei, Ye et Huang, new species}

Holotype: No. 873112, adult male; Wuliang Shan, Jingdong, Yunnan Province. elevation 1900m, collected on March 29, 1987 by Fei Liang.

Allotype: No.873201, adult female; Wuliang Shan, Jingdong, Yunnan Province. elevation 2100m; collected on May 2, 1975.

Paratype: $250^{7} 0^{7}, 2$ \%, collected in the same place as the holotype, elevation 1900-2100m; collected on March 29-30, 1987 by Fei Liang, Huang Yongzhao, Luo Jiarui. 
Diagnostic characters: the main distinguishing differences of this new species from the similar species $M$. lateralis (Anderson) are: snout pointed; big swollen bean-like gland at the posterior part of supratympanic fold; many large warts on side of body; toes with wide fringes; numerous large, dark spots on posterior part of belly and ventral part of thighs; nasals in contact with sphenethmoid; squamosal separated from frontoparietal, prootic on dorsal part entering the orbit. In comparison, in M. lateralis; snout short and rounded; no bean-like gland on posterior part of supratympanic fold; small warts on side of body; toes with narrow fringes; no spots on posterior part of belly and ventral part of thighs; nasal not in contact with sphenethmoid; squamosal in contact with frontoparietal, prootic on dorsal part not entering the orbit.

Description of morphology: male body length $76.3-81 \mathrm{~mm}$, female $76.5-99.5 \mathrm{~mm}$. head flattened, head width slightly larger than head length, snout shield-like, narrow and pointed, obviously extending over mandible; canthus rostralis very distinct, loreal region almost vertical, slightly concave; tympanum distinct; large tongue, pear-shaped, posterior end slightly notched; vomerine ridge very distinct, inclined medially, $3-4$ teeth at end of ridge.

Finger tips ball-like, second finger shorter than first and fourth fingers; no subarticular tubercles, inner metacarpal slightly distinct. Hindlimb long, tibio-tarsal articulation extends anterior to nostril up to tip of snout, right and left heels overlapping, tibia length greater than half of body length; finger tip and toe tip same; third toe slightly longer than fifth toe; toe with very wide fringe (narrow in female), base of toes with rudimentary web; no subarticular tubercles, inner metatarsal tubercles flatten, a little distinct, no outer metatarsal tubercles.

Dorsal skin smooth, more small warts on head and shoulder, less on anterior part of dorsal body, big granules between shoulders forms narrow skin ridge in the shape of a "V"; several distinct small granules on posterior body; both sides of body bear a longitudinal skin ridge formed by small warts. Big warts on lateral body, roughly over ten on each side, small warts dispersed among them; external fringe of upper eyelid bears a undistinguished horn; supratympanic fold long, straight and flat anteriorly, curving over the tympanum extending to the shoulder, and gradually expanded, terminating in a bean-like gland; upper and lower lip margins, temporal region, and tympanum all bear a few small tubercles; edge of upper lip bears small saw tooth-like papillae; dorsal part of fore limbs bear a few small tubercles. Entire ventral skin smooth, a pair of axillary glands located on the chest laterally, very small, distinctly smaller than width of finger tip; round warts at posterior femur are very obvious; femoral gland round, larger than width of toe tip.

Secondary sex characteristics: male has brown black nuptial pads on first and second fingers, and an internal single subgular vocal sac, opening of vocal sac is long and interrupted. 
Table 1. Comparison in morphological characters of three closely-related species of Megophrys

\begin{tabular}{|c|c|c|c|c|}
\hline Species & & M. glandulosa & M. mangshanensis & M. lateralis \\
\hline Location & & Jingdong, Yunnan & Mangshan, Hunan & Mengyang, Yunnan \\
\hline Elevation & & $1900-2100 \mathrm{~m}$ & $1000 \mathrm{~m}$ & $700 \mathrm{~m}$ \\
\hline \multirow{5}{*}{ Head bones } & $\begin{array}{l}\text { anterior end of } \\
\text { ethmoid } \\
\text { cartilage }\end{array}$ & sharp & round & round \\
\hline & $\begin{array}{l}\text { right and left } \\
\text { nasals }\end{array}$ & in contact & separate & in contact \\
\hline & $\begin{array}{l}\text { nasal and } \\
\text { sphenethmoid }\end{array}$ & overlapping & overlapping & separate \\
\hline & $\begin{array}{l}\text { squamosal and } \\
\text { frontoparietal }\end{array}$ & wide separate & in contact & in contact \\
\hline & prootic & entering the orbit & $\begin{array}{c}\text { not entering the } \\
\text { orbit }\end{array}$ & not entering the orbit \\
\hline \multirow{9}{*}{$\begin{array}{l}\text { External } \\
\text { characters }\end{array}$} & snout region & narrow and sharp & wide and round & wide and round \\
\hline & $\begin{array}{l}\text { posterior part of } \\
\text { supratympanic } \\
\text { fold }\end{array}$ & $\begin{array}{l}\text { expand to be } \\
\text { bean-like }\end{array}$ & not bean-like & not bean-like \\
\hline & $\begin{array}{l}\text { warts on dorsal } \\
\text { body }\end{array}$ & big and dense & small and sparse & small and sparse \\
\hline & $\begin{array}{l}\text { fringes on side } \\
\text { of toe }\end{array}$ & very wide & none & narrow \\
\hline & $\begin{array}{l}\text { web between } \\
\text { toes }\end{array}$ & rudimentary web & no web & rudimentary web \\
\hline & $\begin{array}{l}\text { patterns on } \\
\text { dorsal body }\end{array}$ & D) $\quad \because \because \because$ & & $D$ \\
\hline & $\begin{array}{l}\text { stripe of upper } \\
\text { lip margin }\end{array}$ & 1 & 2 & 1 \\
\hline & throat region & $\begin{array}{l}\text { light colored, black } \\
\text { spots on both sides } \\
\text { of throat }\end{array}$ & $\begin{array}{l}\text { dark colored, no } \\
\text { spots on both sides } \\
\text { of throat }\end{array}$ & $\begin{array}{l}\text { light colored, dark } \\
\text { stripes on both sides } \\
\text { of throat }\end{array}$ \\
\hline & $\begin{array}{l}\text { ventral body } \\
\text { and ventral side } \\
\text { of thigh }\end{array}$ & dark spots & no spot & no spot \\
\hline
\end{tabular}


Table 2. Measurements of Megophrys glandulosa

\begin{tabular}{|c|c|c|c|c|c|c|c|}
\hline & $\begin{array}{c}\text { Holotype } \\
0^{7}\end{array}$ & $100^{7} \sigma^{\circ}$ & 3 유 & & $\begin{array}{c}\text { Holotype } \\
0^{2}\end{array}$ & $100^{\circ} 0^{\circ}$ & $3 \% 9$ \\
\hline $\begin{array}{l}\text { Body } \\
\text { length }\end{array}$ & 78.4 & $\begin{array}{c}76.3-81.0 \\
78.2\end{array}$ & $\begin{array}{c}76.5-99.5 \\
87.0\end{array}$ & $\begin{array}{l}\text { Forearm } \\
\text { and hand } \\
\text { length }\end{array}$ & 37.0 & $\begin{array}{c}34.6-38.0 \\
36.4 \\
46.5 \%\end{array}$ & $\begin{array}{c}34.6-43.9 \\
40.0 \\
46.0 \%\end{array}$ \\
\hline $\begin{array}{l}\text { Head } \\
\text { length }\end{array}$ & 28.6 & $\begin{array}{c}27.7-30.5 \\
28.8 \\
36.8 \%\end{array}$ & $\begin{array}{c}28.7-32.6 \\
30.1 \\
34.0 \%\end{array}$ & $\begin{array}{l}\text { Forearm } \\
\text { width }\end{array}$ & 6.8 & $\begin{array}{c}6.5-9.4 \\
7.6 \\
9.7 \%\end{array}$ & $\begin{array}{c}5.6-9.0 \\
7.7 \\
8.9 \%\end{array}$ \\
\hline $\begin{array}{l}\text { Head } \\
\text { width }\end{array}$ & 29.5 & $\begin{array}{c}28.2-31.1 \\
29.4 \\
37.6 \%\end{array}$ & $\begin{array}{c}30.5-35.2 \\
32.1 \\
36.9 \%\end{array}$ & $\begin{array}{l}\text { Hand } \\
\text { width }\end{array}$ & 21.6 & $\begin{array}{c}20.5-23.0 \\
22.0 \\
28.0 \%\end{array}$ & $\begin{array}{c}20.4-21.3 \\
20.7 \\
24.0 \%\end{array}$ \\
\hline $\begin{array}{l}\text { Snout } \\
\text { length }\end{array}$ & 10.8 & $\begin{array}{c}9.3-11.0 \\
10.3 \\
13.2 \%\end{array}$ & $\begin{array}{c}10.2-12.1 \\
11.1 \\
12.8 \%\end{array}$ & $\begin{array}{l}\text { Total } \\
\text { llength } \\
\text { of leg }\end{array}$ & 142.0 & $\begin{array}{c}130.0-146.0 \\
139.6 \\
178.5 \%\end{array}$ & $\begin{array}{c}137.0-161.0 \\
146.3 \\
168.2 \%\end{array}$ \\
\hline $\begin{array}{l}\text { Interorbital } \\
\text { space }\end{array}$ & 8.8 & $\begin{array}{c}7.0-9.5 \\
8.0 \\
10.2 \%\end{array}$ & $\begin{array}{c}8.2-9.4 \\
8.9 \\
10.2 \%\end{array}$ & $\begin{array}{l}\text { Tibia } \\
\text { length }\end{array}$ & 46.8 & $\begin{array}{c}43.9-47.3 \\
46.0 \\
58.5 \%\end{array}$ & $\begin{array}{c}42.3-49.8 \\
47.1 \\
54.1 \%\end{array}$ \\
\hline $\begin{array}{l}\text { Eyelid } \\
\text { width }\end{array}$ & 7.0 & $\begin{array}{l}6.5-7.6 \\
7.0 \\
9.0 \%\end{array}$ & $\begin{array}{c}7.0-8.2 \\
7.4 \\
8.5 \%\end{array}$ & $\begin{array}{l}\text { Tarsal } \\
\text { and foot } \\
\text { length }\end{array}$ & 61.2 & $\begin{array}{c}57.8-64.3 \\
62.0 \\
79.3 \%\end{array}$ & $\begin{array}{c}57.6-71.5 \\
64.6 \\
75.1 \%\end{array}$ \\
\hline $\begin{array}{l}\text { Diameter } \\
\text { of eye }\end{array}$ & 10.0 & $\begin{array}{c}9.7-10.8 \\
10.3 \\
13.2 \%\end{array}$ & $\begin{array}{c}9.0-10.7 \\
9.8 \\
11.3 \%\end{array}$ & $\begin{array}{l}\text { Foot } \\
\text { length }\end{array}$ & 40.6 & $\begin{array}{c}38.8-43.2 \\
41.2 \\
52.7 \%\end{array}$ & $\begin{array}{c}39.0-47.2 \\
44.1 \\
50.7 \%\end{array}$ \\
\hline
\end{tabular}

Note: Measurements in mm, percentages are comparisons with body length.

In life, dorsal body dark brown or brownish gray, brownish black triangular spot appears between eyes, patterns vary tremendously in the middle of dorsum, most often "V"-shaped spot outlined with light colored stripe, on top of shoulder; irregular spots generally on posterior part of dorsum; dorsolateral, longitudinal skin ridge on dorsum dark brown; yellowish white color on top of supratympanic fold, black-brown color on canthus rostralis and below supratympanic fold; a yellowish white longitudinal stripe on upper lip region from nostril to posterior part of angle of jaw; large warts on dorsal body mostly are either bright yellow or part black and part yellow; warts on posterior femur and femoral gland are both bright yellow. Gray, tiny spots show on throat, edge of mandible bears light yellow spots, either side of throat bears an arc-shaped white narrow stripe, external side of stripe appears dark reddish brownish black and extends to anterior shoulder, which forms bilateral symmetrical big spots; yellowish white color on ventral body and ventral part of thigh region, 
region, scattered densely with dark spots; internal part of forelimb and dorsal part of fingers bear very distinct dark spots; dorsal hindlimb brownish gray, bears $3-4$ dark brown transverse stripes; color on dorsal part of limbs are dark, and gradually changes to a lighter color ventrally, ventral parts of metacarpals and metatarsals grayish black, color on ventral part of fingers and toes tips are light.

Characters of skull: Based on skulls of three male specimens No. 873063, 873065 and 873071 and one female specimen No. 873068 , premaxilla almost vertical, alary process of premaxilla slightly inclined forward; anterior part of ethmoid cartiliage narrow and sharp; right and left nasals in contact at the mid-line, nasal and sphenethmoid overlap, not in contact with frontoparietal, sphenethmoid enters orbit on dorsal part; squamosal not in contact with frontoparietal, prootic enters orbit dorsally.

Ecological data: This frog lives in the mountain areas in coniferous and broad-leaf mixed forests at elevations of $1900-2100 \mathrm{~m}$. They occur in slowly flowing streams with bushes and grass growing on both sides of the banks. The water is very clear and there are many rocks in the water. This frog makes a continuous "xia, xia, xia, ......" sound in the afternoon and evening in March and April, making more sounds in the evening. It is very easy to collect them in the evening. In a female collected during the end of March, mature eggs in the belly had entered the fallopian tubes, and the eggs appear milky-yellow in color. The diameter of the eggs is about $2.3 \mathrm{~mm}$, with a total 954 eggs (left side 465, right side 489). Females collected in the early May do not have mature eggs in their bellies. Based on the gravid females collected, this species of frog may have its breeding season in April.
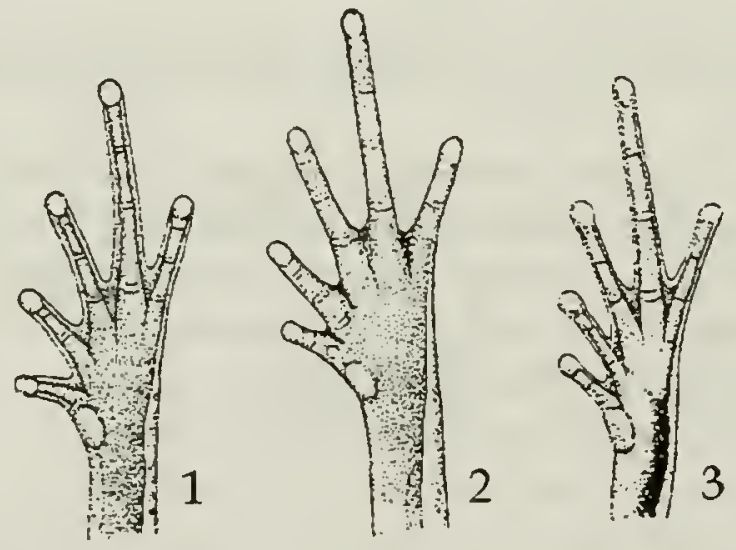

Figure 1. Foot characteristics of three similar species of Megophrys (ventral view) 1. M. glandulosa ơ 2. M. mangshanensis o'. 3. M. lateralis o" (Copied from Liu and $\mathrm{Hu}, 1961)$. 

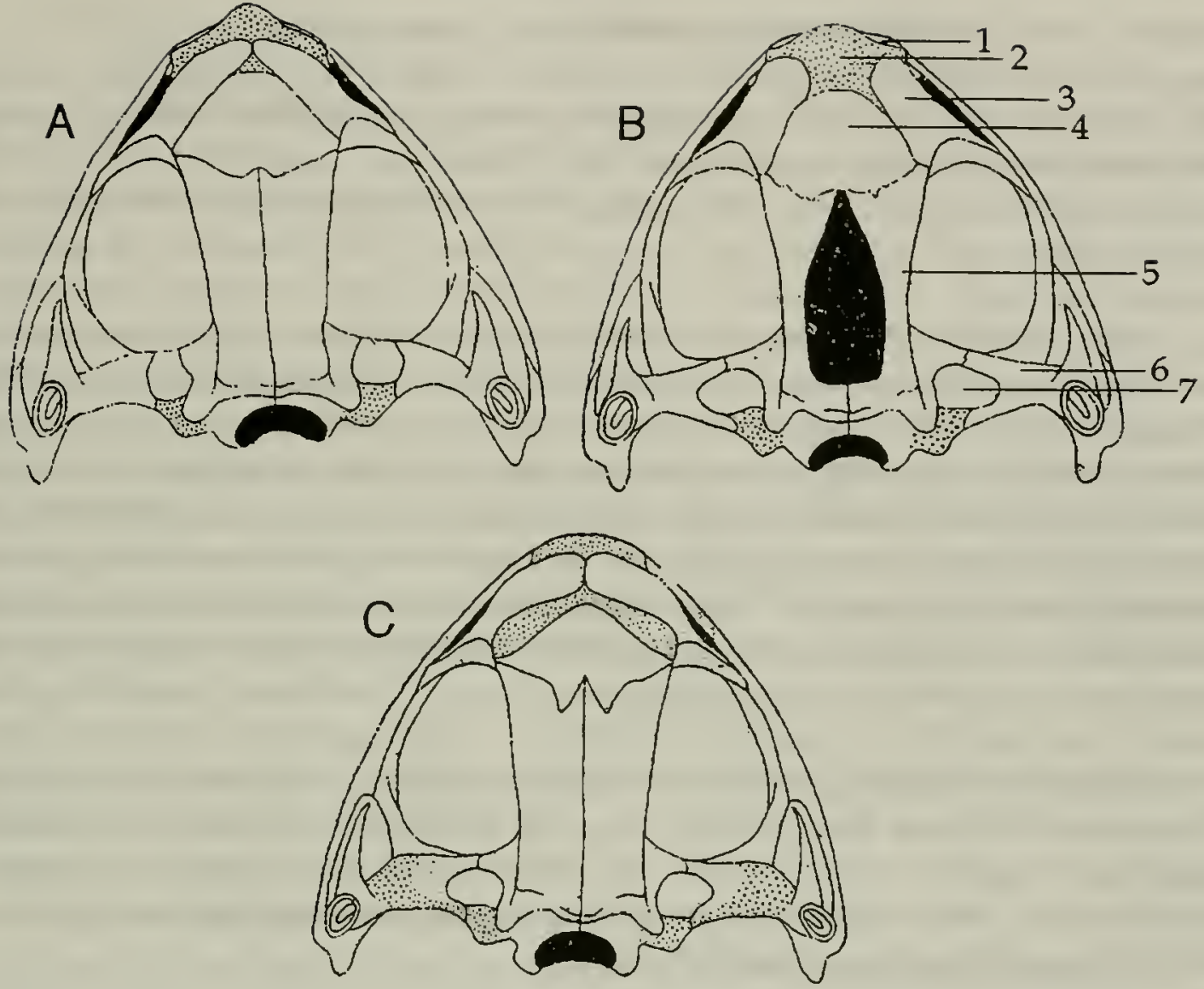

Figure 2. Skull characteristics of three similar species of Megophrys (dorsal view) A. M. glandulosa ơ B. M. mangshanensis o' C. M. lateralis 우

1. alary process of premaxilla; 2. ethmoidcartiliage; 3 . nasal; 4 . sphenethnoid; 5. frontoparietal; 6 . squamosum; 7 . prootic.

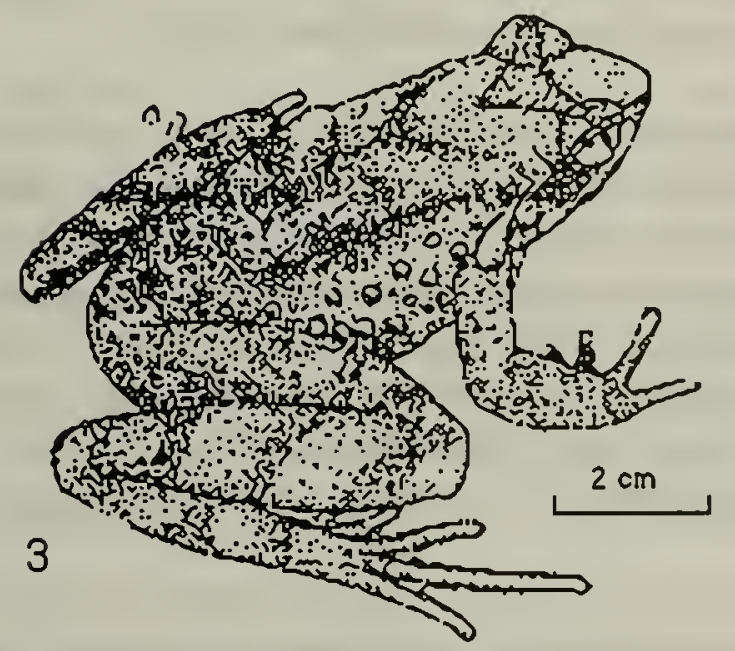

Figure 3. M. glandulosa o";

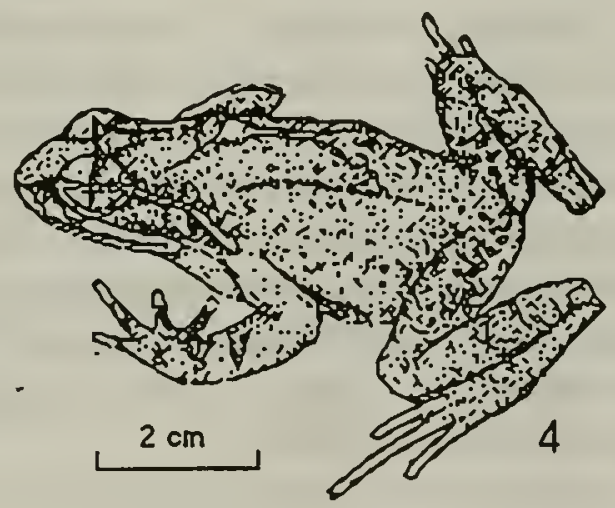

Figure 4. M. mangshanensis ơ. 
Megophrys mangshanensis Fei et Ye, new species

Holotype: No. 75 I 0689, adult female; collected in Mangshan, Yizhang County, Hunan province at $1000 \mathrm{~m}$ elevation on June $10,1975$.

Allotype: No. 75 I 0907, adult male; collected in the same place as holotype on June 25, 1975.

Diagnostic characters: The main distinguishing differences of this new species from its similar species $M$. lateralis (Anderson) are: no lateral fringes on toes and no webbing between toes; a very distinct dark spot on mid-dorsal body, " $X$ "-shaped, connects anteriorly with triangular spot on head; nasals are far separated from each other; nasals in contact with frontoparietal and sphenethmoid, from dorsal view, sphenethmoid does not enter the orbit. In contrast, M lateralis has lateral fringes on toes; webbing basal; dark spot on mid-dorsal body "Y"-shaped, not in contact with triangular spot on head; nasals in contact with each other, but not in contact with frontoparietal or sphenethmoid, from dorsal view, sphenethmoid enters the orbit.

Morphological description: body length of holotype, adult female, is $73 \mathrm{~mm}$, allotype male is $62.5 \mathrm{~mm}$; head flattened; snout tip shield-like, short and round, clearly extends over mandible; canthus rostralis very distinct, loreal region vertical and concave; tympanum clear; tongue pear-shaped; posterior end weakly notched; vomerine ridge very distinct, its posterior end large, bearing 3-4 teeth.

Finger tips ball-like, second finger shorter than first and fourth fingers; no subarticular tubercles, inner metacarpal tubercles weakly distinct. Hindlimb short, tibio-tarsal articulation reaches eye; right and left heels overlap, tibia length over half of body length, toe tips ball-like, third toe longer than fifth toe, no lateral fringes on toes, no webbing between toes (rudimentary web between metatarsals); no subarticular tubercles, inner metacarpal tubercle flattened, slightly distinct, no outer metatarsal tubercle.

Dorsal skin smooth, "V"-shaped narrow ridge formed by thin warts on posterior part of head are not very distinct, either side of dorsal body bears a longitudinal skin ridge formed by small warts, many small white spiny warts on posterior body; warts on both sides of body smaller. A small horn on upper eyelid; upper lip margin bears saw toothlike papillae; supratympanic fold long, curving over tympanum to shoulder (it is more straight and flattened in males compared to females), its hind part a little thicker, no beanlike gland; white warts on temporal region. Dorsal body of hindlimb smooth, a few warts appear on posterior thigh. A pair of axillary glands and femoral glands, about equal to width of finger tip and toe tip.

Secondary sex characters: first and second fingers of males bear brown nuptial pads, internal single subgular vocal sac exists, opening of vocal sac long and interrupted. 
In life, dorsal head yellowish green, body color changes gradually from yellowish green to purplish gray from anterior body to top of vent; dark reddish brown triangular marking appears between eyes, center of marking light green, its hind edge mixes with anterior part of " $X$ "-shaped marking. The " $X$ "-shaped marking on mid-dorsal body and longitudinal skin ridge on lateral body are all purple color; both sides of posterior part of markings are in contact with longitudinal stripes on lateral body; all edges of these marking and stripes are outlined with orange-yellow narrow lines. Color from canthus rostralis to lower part of supratympanic fold are purple-red; upper lip edge dark red, bearing two yellowish white markings, one below loreal region, another narrow and long stripe starts from below eye to a level below tympanum. Lateral body light purple, warty region grayish white, a broken light purple-gray longitudinal stripe appears from posterior axilla to middle part of sides of the belly, either distinct or indistinct. Dark purple color on throat and chest, dispersed with orange-red, milky white and yellowish green small spots; ginger-yellow color on both posterior belly and ventral part of thigh, with orangered, black-gray small spots scattered around. Dorsal parts of forelimbs are purple-gray bearing indistinct purple-black narrow transverse stripe, colors changes from dorsum being purple-black becoming lighter on the belly; dark purple at posterior part of thigh, bearing sparsely black and milky white spots; ventral parts of fingers and toes grayish white.

Table 3: Measurement of M. mangshanensis

\begin{tabular}{|c|c|c|c|c|c|}
\hline & $\begin{array}{c}\text { Holotype } \\
\wp\end{array}$ & $\begin{array}{c}\text { Allotype } \\
\sigma^{\prime}\end{array}$ & & $\begin{array}{c}\text { Holotype } \\
\text { o }\end{array}$ & $\begin{array}{c}\text { Allotype } \\
0^{0}\end{array}$ \\
\hline Body length & 73.0 & 62.5 & $\begin{array}{l}\text { Forearm and hand } \\
\text { length }\end{array}$ & $\begin{array}{c}33.6 \\
46.0 \%\end{array}$ & $\begin{array}{c}26.3 \\
42.1 \%\end{array}$ \\
\hline Head length & $\begin{array}{c}27.3 \\
37.4 \%\end{array}$ & $\begin{array}{c}22.1 \\
35.4 \%\end{array}$ & Forearm width & $\begin{array}{c}5.4 \\
7.4 \%\end{array}$ & $\begin{array}{c}5.4 \\
8.6 \%\end{array}$ \\
\hline Head width & $\begin{array}{c}28.4 \\
38.9 \%\end{array}$ & $\begin{array}{l}22.0 \\
35.2 \%\end{array}$ & Hand length & $\begin{array}{c}18.9 \\
25.9 \%\end{array}$ & $\begin{array}{c}16.3 \\
26.1 \%\end{array}$ \\
\hline Snout length & $\begin{array}{l}10.0 \\
13.7 \%\end{array}$ & $\begin{array}{c}7.5 \\
12.0 \%\end{array}$ & Total length of leg & $\begin{array}{c}118.0 \\
161.6 \%\end{array}$ & $\begin{array}{c}99.0 \\
158.4 \%\end{array}$ \\
\hline Interorbital space & $\begin{array}{c}8.9 \\
12.2 \%\end{array}$ & $\begin{array}{c}7.7 \\
12.3 \%\end{array}$ & Tibial length & $\begin{array}{c}39.7 \\
54.4 \%\end{array}$ & $\begin{array}{c}32.4 \\
51.8 \%\end{array}$ \\
\hline Eyelid width & $\begin{array}{l}7.2 \\
9.9 \%\end{array}$ & $\begin{array}{l}5.8 \\
9.3 \%\end{array}$ & Tarsal and foot length & $\begin{array}{c}53.2 \\
72.9 \%\end{array}$ & $\begin{array}{c}43.0 \\
68.8 \%\end{array}$ \\
\hline Diameter of eye & $\begin{array}{c}9.6 \\
13.2 \%\end{array}$ & $\begin{array}{l}8.0 \\
12.8 \%\end{array}$ & Feet length & $\begin{array}{c}33.6 \\
46.0 \%\end{array}$ & $\begin{array}{c}27.7 \\
44.3 \%\end{array}$ \\
\hline
\end{tabular}


Skull characters: Based on the skull morphology of a female specimen 75 I 0689 and male specimen 75 I 0907, premaxilla inclined forward, from ventral view, alary process of premaxilla large; anterior part of ethmoid cartiliage wide and round; right and left nasals far separated from each other, but in contact with the sphenethmoid and frontoparietal bones; from dorsal view, sphenethmoid does not enter the orbit; center of frontoparietal weakly ossified (75 I 0689) or not ossified (75 I 0907); squamosal and frontoparietal bone in contact (or fused), prootic does not enter the orbit from dorsal part.

Ecological data: This species of frogs lives either in streams of evergreen broad-leaf areas or in rich vegetated forests at about $1000 \mathrm{~m}$. Fallen leaves below the trees are thick, and streams are very clear, many small and big rocks occur in the streams. In middle and late June, this frog hides under fallen leaves on the roadside slopes about $20-30 \mathrm{~m}$ from streams.

\section{References}

Sichuan Institute of Biology. 1976. Survey report of amphibians in Mangshen, Yizhang, Hunan Province. Materials for Herpetological Research, 3: 24-26. [In Chinese].

Sichuan Institute of Biology. 1977. Systematic Keys to Chinese Amphibians. 1-93 Science Pubulishing House. [In Chinese].

Liu Cheng-zhao, Shuqin Hu. 1961. Tailless Amphibians of China. 1-364 Science Publishing House. [In Chinese].

Anderson, J. 1871. [sic A list of the reptilian accessions to the Indian Museum, Calcutta, from 1865-1870, with a description of some new species.] Jour. Asiat. Soc. Bengal, 40: 29 [sic 12-39].

Boulenger, G. A. 1855. Description of a new frog of genus Megalophrys. Proc. Zool. Soc., 850 , pl. LV.

Boulenger, G.A. 1908. A revision of the Oriental pelobatid batrachians (genus Megalophrys). Proc. Zool. Soc. London, 407-430.

Liu, C. C. 1950. Amphibians of Western China. Fieldiana: Zool. Mem., 2:1-400.

Mell, R. 1922. Beiträge zür Fauna Sinica I. Die vertebraten Südchinas: Reptilien und Batrachier, Arch. Naturg. Berlin, 88A, (10): 128-134.

Pope, C. H. 1931. Notes on amphibians from Fukien, Hainan and other parts of China. Bull. Amer. Mus. Nat. Hist., 61(8): 397-611.

Pope, C. H. and A. M. Boring. 1940. A survey of Chinese Amphibia. Peking Nat. Hist. Bull., 15(1): 13-36. 
